Article

\title{
Evaluating Centralized and Heterarchical Control of Smart Manufacturing Systems in the Era of Industry 4.0
}

\author{
Anna Rosaria Boccella ${ }^{1}$, Piera Centobelli ${ }^{2, *}$, Roberto Cerchione ${ }^{3}$, Teresa Murino ${ }^{4}$ and \\ Ralph Riedel ${ }^{5}$ \\ 1 Klüber Lubrication München SE \& Co. KG Geisenhausenerstraße 7, 81379 Munich, Germany; \\ annar.boccella@gmail.com \\ 2 Department of Industrial Engineering, University of Naples Federico II, P.le Tecchio 80, 80125 Naples, Italy \\ 3 Department of Engineering, University of Naples Parthenope, Centro Direzionale di Napoli, Isola C4, \\ 80143 Naples, Italy; roberto.cerchione@uniparthenope.it \\ 4 Department of Chemical, Materials and Industrial Production Engineering, University of Naples Federico II, \\ P.le Tecchio 80, 80125 Naples, Italy; murino@unina.it \\ 5 Department of Factory Planning and Factory Management, Technische Universität Chemnitz, \\ ErfenschlagerStraße 73, 09125 Chemnitz, Germany; ralph.riedel@mb.tu-chemnitz.de \\ * Correspondence: piera.centobelli@unina.it
}

Received: 14 November 2019; Accepted: 14 January 2020; Published: 21 January 2020 updates

\begin{abstract}
In light of the Fourth Industrial Revolution, the concepts of flexibility and re-configurability of manufacturing systems and the evolution of their control architectures are becoming increasingly important. The development of Cyber Physical Systems (CPS) and their flexibility and integrated capabilities have paved the way to the transition from centralized control to heterarchical (decentralized) control architectures. In this paper, a comparison between centralized and heterarchical control architectures in a virtual learning environment is presented. The control architectures of the assembly station and the materials handling system of modern manufacturing systems have been conceptualized and tested under different working conditions. The results show that centralized control is the best solution only for deterministic and predictable scenarios, which are very far from reality, whereas, in case of failures, a more flexible control is preferable.
\end{abstract}

Keywords: decentralized production; Flexible Manufacturing Systems; Industry 4.0; manufacturing control architectures; reconfigurable manufacturing systems; smart manufacturing systems

\section{Introduction}

The demand for more personalized, smart, and sustainable products has led to the rapid growth of the industrial Internet and cyber-physical technologies completely revolutionizing the manufacturing systems [1] The industrial world has switched from classical manufacturing systems to smart manufacturing systems based on self-contained, automated, and smart modules, exploiting flexibility and re-configurability capabilities.

The Fourth Industrial Revolution (also known as Industry 4.0, Industrie 4.0, or I4.0) and related technologies have led to a significant evolution and transformation of the manufacturing systems. The key principles behind I4.0 are interconnection, information transparency, decentralized decisions, and real time technical assistance for human operators [2]. All parts of the manufacturing system should be connected with each other and have common data models. Manufacturing processes are therefore required to be significantly digitalized and simulation techniques are now paving the way to the 'digital factory' concept, a mix of virtual and real factory environments. Digital factory is defined 
as a "comprehensive network of digital models, methods and tools-including modelling, simulation and 3D/virtual reality visualization —integrated by continuous data management" [3] to simulate real manufacturing systems and optimize their performance. The digital factory applies production planning and control principles aimed at optimizing production systems to face more complex and competitive environments.

In the I4.0 paradigm, modern manufacturing systems have to ensure re-configurability, flexibility, and intelligence. This result can be reached by more autonomous control systems. The Industry 4.0 paradigm emphasizes the development of Cyber-Physical Systems (CPS), digitalization, and interconnectivity. CPS are defined as an integration of resources from physical and cyber domains. In CPS, the computational resources from cyber world monitor the feedback from physical process hence dynamically computing the scenarios to generate control signals. By integration of new computational tools into manufacturing systems, CPSs have attained functionalities which are beneficial for enhancing productivity, quality, and reducing expenses. The communication capabilities were ensured by the Industrial CPS (ICPS), well-defined interfaces that enable CPS to integrate and communicate with the existing systems [4].

In this context, the traditional manufacturing production systems shift into smart production systems. Smart production systems are defined as fully integrated collaborative manufacturing systems that respond in real time to the changing demands and conditions of the factory, the supply network, and customer needs through digitalization of the manufacturing system [1]. These systems are characterized by advanced sensors, service-orientation, connected and autonomous CPS objects, collaborative supply networks, integrated and decentralized decision-making, interoperability, flexibility, and advanced analytics [5].

Advanced computational models are indeed required for addressing these capabilities [6]. These emerging architectural paradigms have to be transformed from static, rigid, and hierarchical into smart architectures composed and matched in a decentralized and dynamic fashion to accommodate the requirements of higher flexibility and reconfigurability [7].

In centralized control, a single component controls all the manufacturing entities. On the contrary, heterarchical control systems are customized and made up of several autonomous components able to communicate each other [8].

Switching from a centralized to a heterarchical (or decentralized) control can lead to a more efficient environment for production, especially in the case of deviations from ordinary working conditions [9]. This is why, nowadays, there is a growing interest in modular manufacturing systems and solutions supporting independent entities to communicate and operate autonomously, like multi-agent systems (MASs) [10].

This paper presents a comparison of two production control architectures: centralized and heterarchical. Digital factory tools were used to simulate production planning and control of manufacturing systems and assess the advantages of self-controlled production systems.

For the experimental phase, an assembly line built with Lego ${ }^{\circledR}$ Mindstorms ${ }^{\circledR}$ EV3 was used as a physical prototype of the production system. Starting from the comparison between centralized and heterarchical control applied to the Lego ${ }^{\circledR}$ system, the testing phase was conducted using the Siemens Tecnomatix Plant Simulation 11.0 software, a computer application developed by Tecnomatix Plant Simulation 11.0 software for modeling, simulating, analyzing, visualizing, and optimizing production systems and processes, the flow of materials, and logistic operations. Afterwards, other experiments were carried out in the Experimental and Digital Factory (EDF) laboratory of the Technische Universität at Chemnitz, to obtain more relevant results from the comparison of centralized and heterarchical control of material handling systems.

The remainder of this paper is organized as follows. After this introduction, Section 2 presents a review of the manufacturing systems, from the origins to the modern era, with a focus on control architectures. Section 3 describes the methodology used, the main research steps and the criteria applied. Section 4 describes the scenarios considered for the experiments. Section 5 deals with the 
application of a digital factory concept- the simulation model obtained using the Siemens Tecnomatix Plant Simulation 11.0 software-to apply the theoretical concepts previously described. Results and discussions are presented in Section 6. Section 7 presents some final conclusions and directions for future work.

\section{Evolution of Manufacturing Systems}

The interest in optimizing production planning and control has been growing for the past few years. Customers' demands are changing, asking for high quality finished goods at low prices and with a shorter time-to-market. In this scenario, factories can survive and outperform their competitors switching to flexible and reconfigurable manufacturing systems [11].

A Flexible Manufacturing System (FMS) is an integrated and computer-controlled system of automated material handling devices and numerically controlled (NC) machine tools that can simultaneously process medium-sized volumes of part types [12]. It can be considered as a system able to cope with machine failures or breakdowns [13] and able to check its own state as well as the availability of its resources [14].

A reconfigurable manufacturing system is a system designed so as to allow for rapid changes in structure, both hardware and software, in order to rapidly adjust the production capacity and functionality of a part family in response to sudden changes in market or in regulatory requirements [15].

These new manufacturing system characteristics led to significant changes in production control systems supervising systems different activities (e.g., a control action can be applied on the sequence of products that have to be manufactured, on the tuning operations of a production system or on operations aimed at restoring the proper functionality of the process) [16]. From the manufacturing point of view, a control system is used to control the manufacturing process, to set the run-mode to meet market requirements or to set the sequence of tasks that a processing unit has to perform, to optimize the production process [17]. Therefore, the final aim of a control system is coordinating and directing all the production activities [8] and monitoring the production system to prevent undesired functioning [16].

Four types of control architectures have been identified for automated manufacturing systems: centralized control, proper hierarchical control, modified hierarchical control, and heterarchical (or decentralized) control [8].

The centralized control architecture is represented by a mainframe computer that performs all planning and information processing functions [18]. In this case, all control decisions are taken at a unique location. This control architecture is characterized by a single component controlling all manufacturing entities, e.g., robots, production sites, and handling systems [8]. All control architectures have advantages and disadvantages. In centralized control, the advantages lie in the opportunity to identify and reach a global optimization condition and to acquire information about the system from a single component. The disadvantages are slow response and dependence on a single component and restrictions in modifying the control software [8].

The second typology of control architecture is proper hierarchical control. In this case, different control components are organized in a pyramidal structure [19], where every manufacturing entity is controlled by a superior control component, but at the top of the pyramid a single component is responsible for the whole control. The control operations are executed with a top-down strategy, while the reports, deriving from control actions, are supplied with a bottom-up strategy. The advantages of proper hierarchical control are less software restrictions and quicker responses, while some disadvantages are related to the computational restriction of control entities, difficulty in applying unexpected modifications, and the high amount of interrelations between manufacturing entities and control components [8].

The modified hierarchical control is similar, as the name suggests, to proper hierarchical control: the pyramidal structure of control components and the related manufacturing entities to be controlled still exist but the level of autonomy of control components-subordinated to the global control 
component-is different. In this case, the control components in higher positions in the pyramid do not have a rigid control on lower levels but all the control operations are coordinated. Modified hierarchical control offers the same advantages as proper hierarchical control and furthermore, every control component has a higher level of autonomy. In addition to the disadvantages of proper hierarchical control, the design phase of the control system is challenging [8].

Finally, the fourth typology of control architecture is the heterarchical control. It was introduced to overcome most of the disadvantages of the other control architectures [18-23]. The conventional pyramidal structure of the hierarchical control architecture disappears. Every control component, as well as manufacturing entities, communicates with the others preserving its autonomy. Heterarchical control is a mix of local autonomy and cooperative relationships to obtain an efficient control of the system in real time [8]. There are several advantages in applying heterarchical control: software development is less complex, the manufacturing system is easily reconfigurable, there is a fast information exchange, and disruptions can be easily managed due to the flexibility and reconfigurability capabilities of control components and manufacturing entities. This control has some disadvantages since it requires a high network capacity, it has no standards for communications, and control components could have technical limits [8].

Centralized and heterarchical control architectures can be considered as the two opposite ends of a continuum. In a centralized control system, there is a single decision maker, in a heterarchical control system, every manufacturing entity can be considered as an autonomous decision maker [24]. The latter condition appears to be effective in obtaining a real flexible manufacturing system, able to change and adapt to external changes. Even if it seems to be the most promising one [25], a study to identify the best control architecture in various real scenarios and the circumstances that determine the best control architecture is still required.

Furthermore, changes in the use of information and communication technologies also contributed to the evolution of control systems architectures. The stochastic behavior of manufacturing systems led to development of heterarchical control system [26,27].

The implementation of a heterarchical control system is possible thanks to the concept of 'agent' technology, able to manage the information real time [28] and create platforms that let users control the manufacturing systems in a more dynamic way [29]. An agent is an encapsulated computer system or computer program that is situated in some environment and that is capable of flexible and autonomous actions to meet its design objectives or goals [30]. Thus, it is able to overcome perturbations in the manufacturing environment autonomously, since it is able to control both its own state and the external state of other agents [31]. In most cases, more than one agent is used inside a manufacturing system. A MAS is used to distribute the system intelligence aiming to run the service re-configuration process in an autonomous, modular, and decentralized mode [32]. This is used to distribute the responsibilities of actions inside the system and create a reliable system able to accomplish tasks also in case of failures, because there is always another agent ready to replace the failed one [30]. The typical architecture of MAS is heterarchical, it means that different and independent control components are used as decision makers inside a factory [10]. Therefore, the heterarchical control paradigm makes control systems self-organized, able to manage industrial production complexity [33] and face internal and external disruptions leading to a higher level of flexibility [34].

Several empirical studies of control systems with different aims have been found in the literature [35,36]. Brennan and Douglas (2003) evaluate hierarchical and heterarchical control architectures using two different metrics, i.e., the manufacturing system and the control system [37]. Moyaux and McBurney (2012) compare heterarchical and centralized control in information technology using, as an example, climate control, for which the most energy-efficient is the most intelligent control [38]. Other applications regard the time that trays in a manufacturing system take to reach a specific destination [39], the test-bed experimentation to compare hierarchical and heterarchical control [25], or even the application of centralized and heterarchical control on the Supply Chain to 
solve the bullwhip effect problem [40]. Also, the use of heterarchical control to forecast the actions of Automated Guided Vehicle (AGV) has been investigated considering AGVs as smart agents [41].

Nowadays, manufacturing systems operate in a dynamic environment, where perturbations and failures are frequent. A more in-depth study comparing the two main control architectures (i.e., centralized and heterarchical control systems) is required.

Based on these premises, this study aims to address the following research question:

RQ: Under what circumstances centralized and heterarchical control systems operate better?

\section{Methodology}

A comparison of centralized and heterarchical control architectures is presented in this paper to identify their pros and cons. The starting point of the paper was the identification of the manufacturing system on which the simulations could be carried out. To test the control principles, a physical model of a manufacturing system was chosen [42].

Two scenarios were considered in this paper. In the first scenario, centralized and heterarchical control were applied to assembly stations, while in the second scenario the control architectures were tested for materials handling systems. In the first scenario, the final product is obtained assembling $2 \times 2$ yellow Lego ${ }^{\circledR}$ brick on a green one. In the second scenario the final product is obtained assembling three metallic parts with a black plastic cover and different materials handling systems were used to transport the elements in the manufacturing system.

Figure 1 shows the two scenarios and the control methods applied. As indicated in the conceptual framework, the field of application of centralized and heterarchical control is different in both scenarios even if the control principles remain the same.

According to Güldenpfennig (2011) and Leduc et al. (2006), centralized control consists in centralized decision-making system $[43,44]$. In the first scenario, the assembly stations were fixed and there were no possibilities to change the production schedule. In the second scenario, the materials handling system was defined a priori. Conversely, heterarchical control consists in applying the agent technology concept [30] to create flexible elements able to communicate and cooperate autonomously $[35,41]$. In this latter case, the assembly stations (first scenario) and the material handling systems (second scenario) were not defined a priori.

Basically, the theoretical centralized and heterarchical control concepts were translated as:

- Selection principle of the processing assembly station (Scenario 1);

- Selection principle of the material handling system (Scenario 2).

Thus, in the first scenario, centralized control consisted in predefining the assembly stations (AS) (i.e., the first product was assigned to the Assembly Station 1 (AS1), the second product to Assembly Station 2 (AS2), the third product to AS1, and so on). Conversely, heterarchical control consisted in testing a more flexible control since the assembly stations were chosen considering their availability real time. Whenever a raw material was released, AS1 was questioned about its availability, if it was free the product was assembled in AS1, if not AS2 was questioned to check its availability. In cases where both assembly stations were unavailable, a non-manufactured unit occurred. Under heterarchical control, failures can be managed in a proper way: in the case of failure of AS1, the finished product can be assembled in the AS2.

In the second scenario, the same principles of centralized and heterarchical control were applied. Under centralized control, the material handling systems were predefined, whereas under heterarchical control, the selection of the material handling system was based on its availability.

These principles were applied to the physical models for both scenarios. Afterwards, the physical systems were used to collect data and create simulation models to widen the scope of the research work. 
Centralized control

- Route planning defined by a centralised decision-making system (Leduc, Lawford and Dai, 2006)

\section{Heterarchical control}

- "agent" technology (L.van Moergestel, 2015)

- Independent and flexible elements (Ramli et al., 2009a)

- Communication, exchanging information and cooperation among agents (Ramli, 2009b)

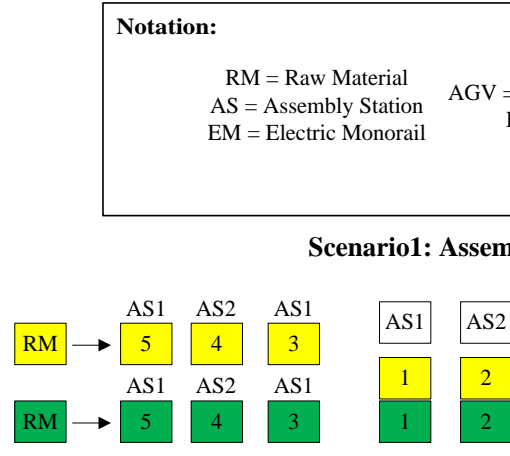

Non-manufactured uni RC $=$ Roller Conveyor
Rutomated Guided Vehice Decision gate $=$ Control application

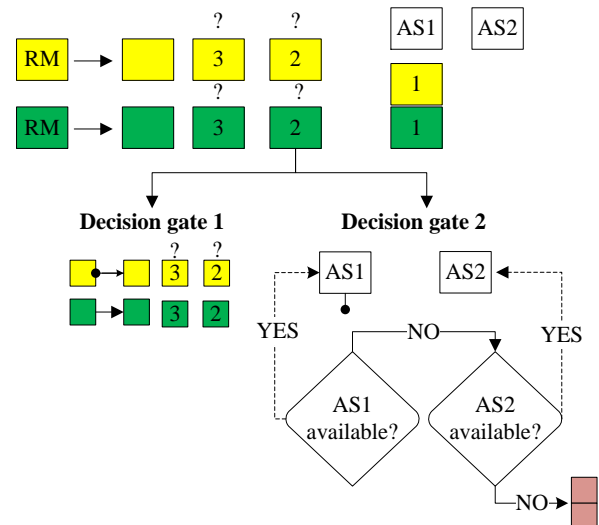

Scenario2: Handling systems (EDF-Experimental and Digital Factory)
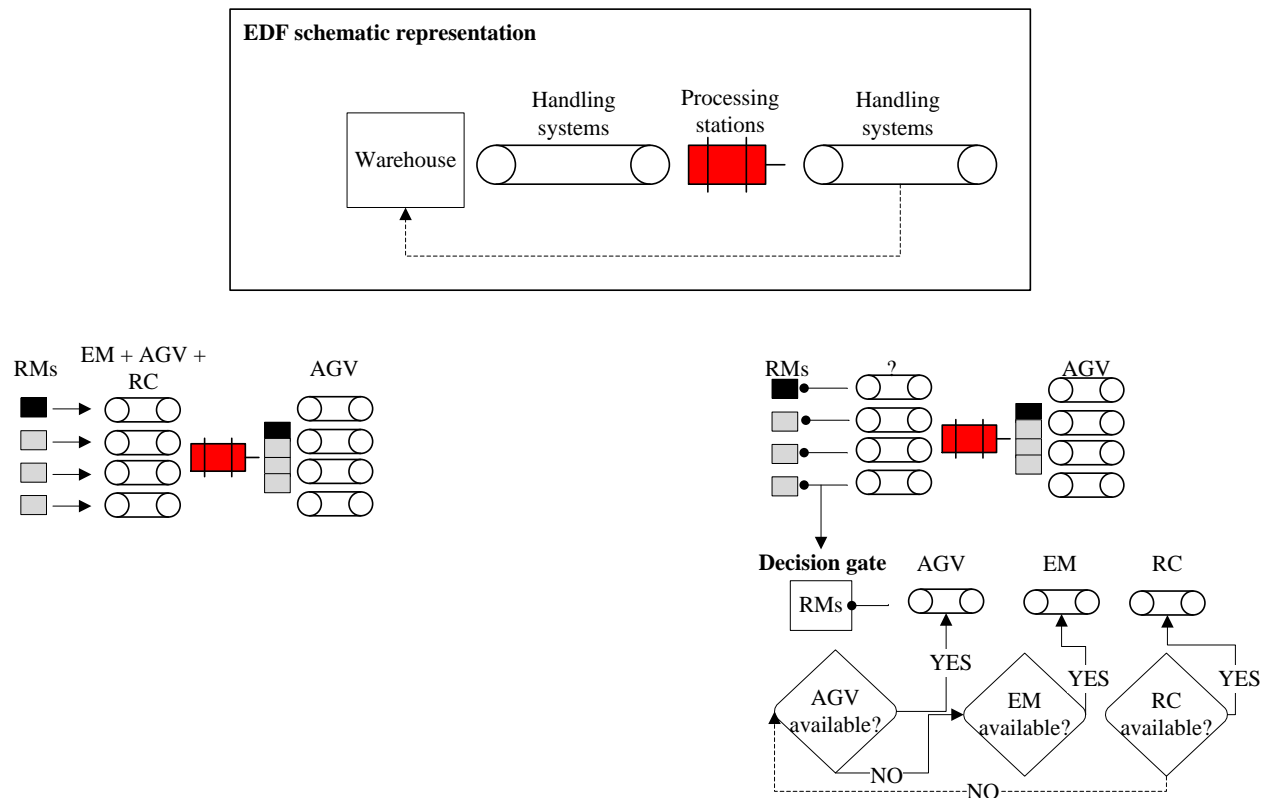

Figure 1. Conceptual framework.

\section{Experimental Scenarios}

The experimental phase was carried out considering the two scenarios described above:

Scenario 1: The experimental phase based on assembly stations control;

Scenario 2: The experimental phase based on material handling systems control.

To test these scenarios, two physical prototypes are required. Therefore, the Lego ${ }^{\circledR}$ and the EDF model which will be detailed below represent the physical prototypes developed to test centralized and heterarchical control architectures described above. 


\subsection{Scenario 1: Testing Assembly Stations}

In the first scenario, the experiments were carried out in the assembly stations of a production line using a physical model built with Lego ${ }^{\circledR}$ Mindstorms ${ }^{\circledR}$ EV3 and reported in Figure 2.

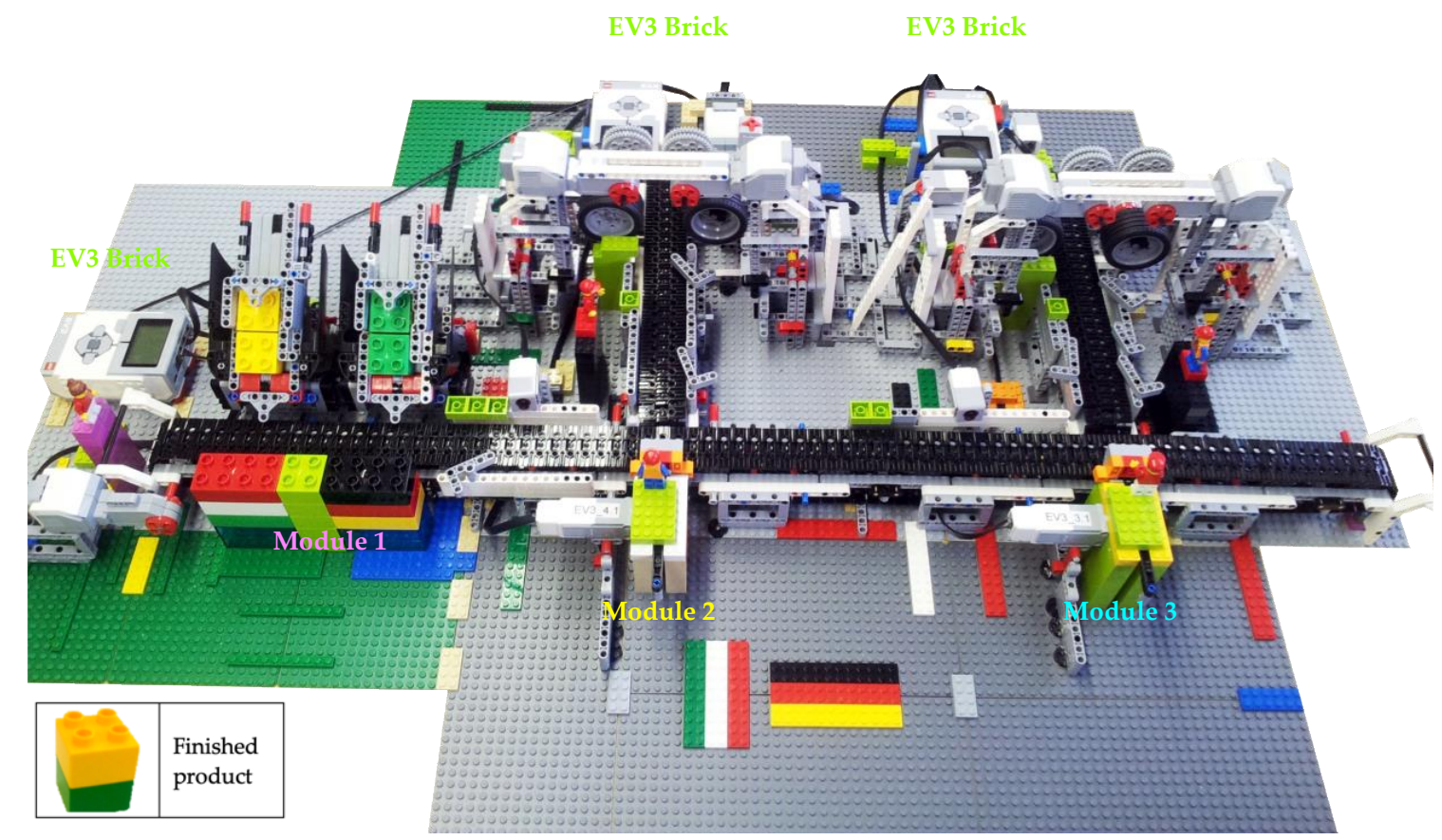

Figure 2. Lego ${ }^{\circledR}$ Mindstorms ${ }^{\circledR}$ EV3 prototype.

This is a prototype of an assembly line built by the authors and programmed using the Lego ${ }^{\circledR}$ Mindstorms ${ }^{\circledR}$ EV3 software to assemble two $2 \times 2$ Lego ${ }^{\circledR}$ bricks (one yellow on the top and one green at the bottom) (bottom left in Figure 2).

The Lego ${ }^{\circledR}$ physical model is characterized by a modular structure and it is composed by three modules as detailed in Figure 2 and described below:

- Module 1: Warehouses for raw materials (RM) and Main Conveyor Belt (highlighted in pink in Figure 2). It includes two warehouses for raw materials-one for yellow Lego ${ }^{\circledR}$ bricks and the other one for green Lego ${ }^{\circledR}$ bricks—and the Main Conveyor Belt (length: $95 \mathrm{~cm}$ ) which connects the warehouses for raw materials to the other modules of the processing line.

- $\quad$ Module 2: Assembly Station 1 (AS1) + Distribution system 1 (highlighted in yellow in Figure 2). It includes the first assembly station-made up of two wheels rotating in opposite directions that assemble a yellow brick on a green Lego ${ }^{\circledR}$ brick—and the first distribution system made up of a rack moved by a medium motor which pushes all the necessary Lego ${ }^{\circledR}$ bricks towards the assembly station.

- Module 3: Assembly Station 2 (AS2) + Distribution system 2 (highlighted in light blue in Figure 2). It includes the second assembly station and the second distribution system working exactly as the Module 2.

Every module is controlled by an EV3 Brick, which is the brain of the physical prototype (highlighted in green in Figure 2). The EV3 Bricks are connected via Bluetooth, and for this kind of connection the EV3 Bricks are divided into Master Bricks and Slave Bricks. Master EV3s and Slave EV3s can send messages between each other via Bluetooth. 


\subsection{Scenario 2: Testing Material Handling Systems}

In the second scenario, the experiments were carried out to compare centralized and heterarchical control of the material handling systems, used for the assembly process of the finished product reported in Figure 3. In this scenario, the final product is made in the EDF laboratory of the Technische Universität at Chemnitz (Figure 4). The EDF is divided into two sections: the Experimental Center (including all the facilities and their components) and the Digital Center (including all the components related to factory planning and visualization). The material handling systems available in the EDF to move materials and components within the manufacturing plant are the electric monorail (EHB), the AGV, and the roller conveyor (RC).
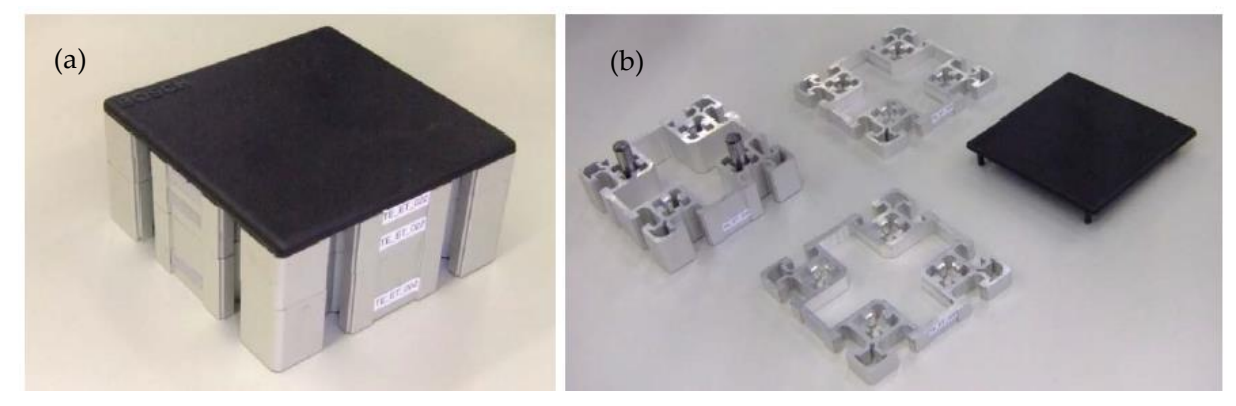

Figure 3. (a) Finished product; (b) Products' components.
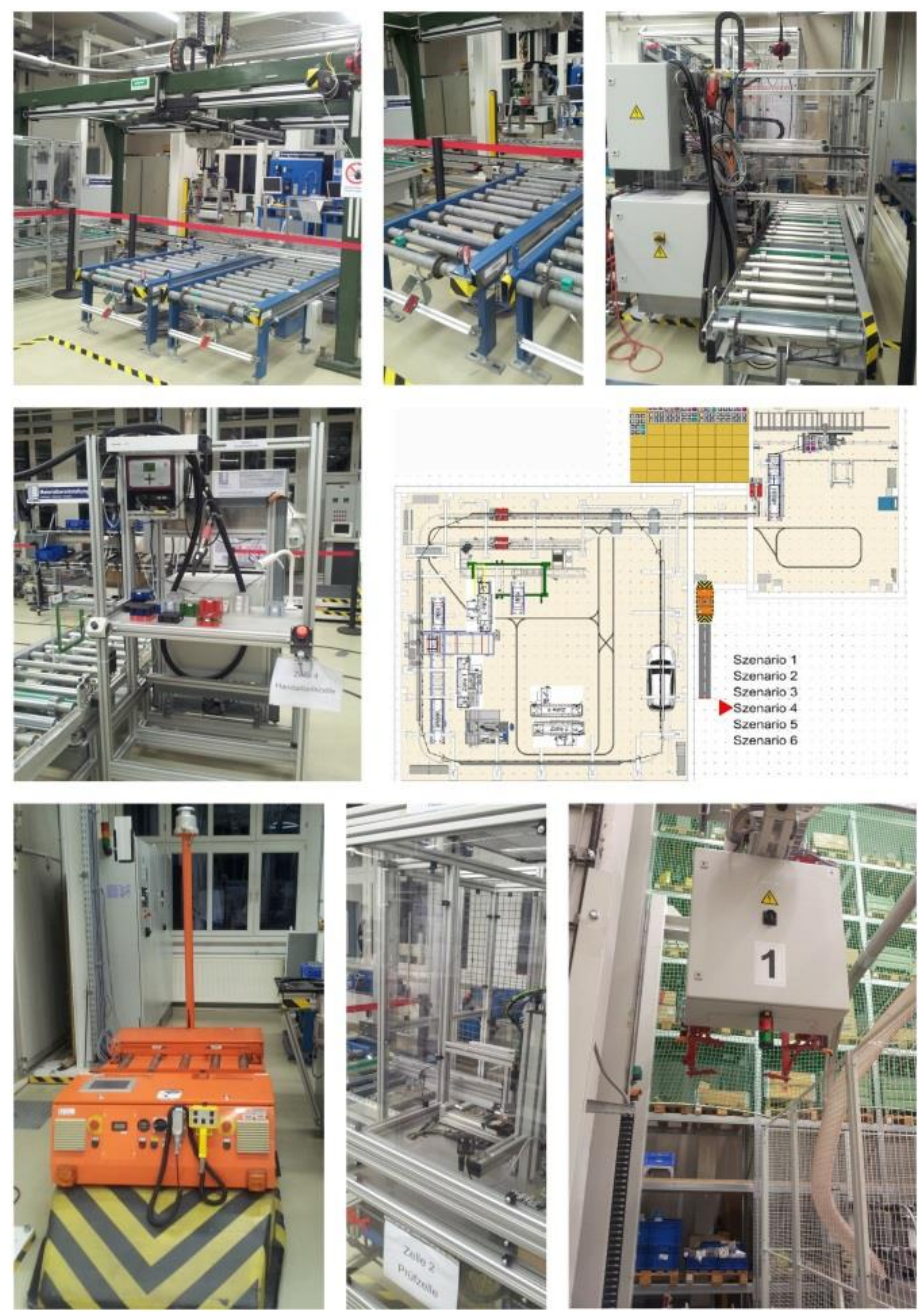

Figure 4. EDF areas. 


\section{Simulation Models Settings}

The simulation model was developed using computer programs that let users analyze a system in terms of procedures and efficiency, but also apply and compare different control principles on flexible and reconfigurable manufacturing systems [45].

The Tecnomatix Plant Simulation 11.0 software by Siemens was used for the simulation of the manufacturing system models. Two simulation models were built to compare centralized and heterarchical control of both assembly stations and material handling systems.

\subsection{Scenario 1}

The simulation model reproducing the behavior of Lego ${ }^{\circledR}$ physical model is represented in Figure 5.

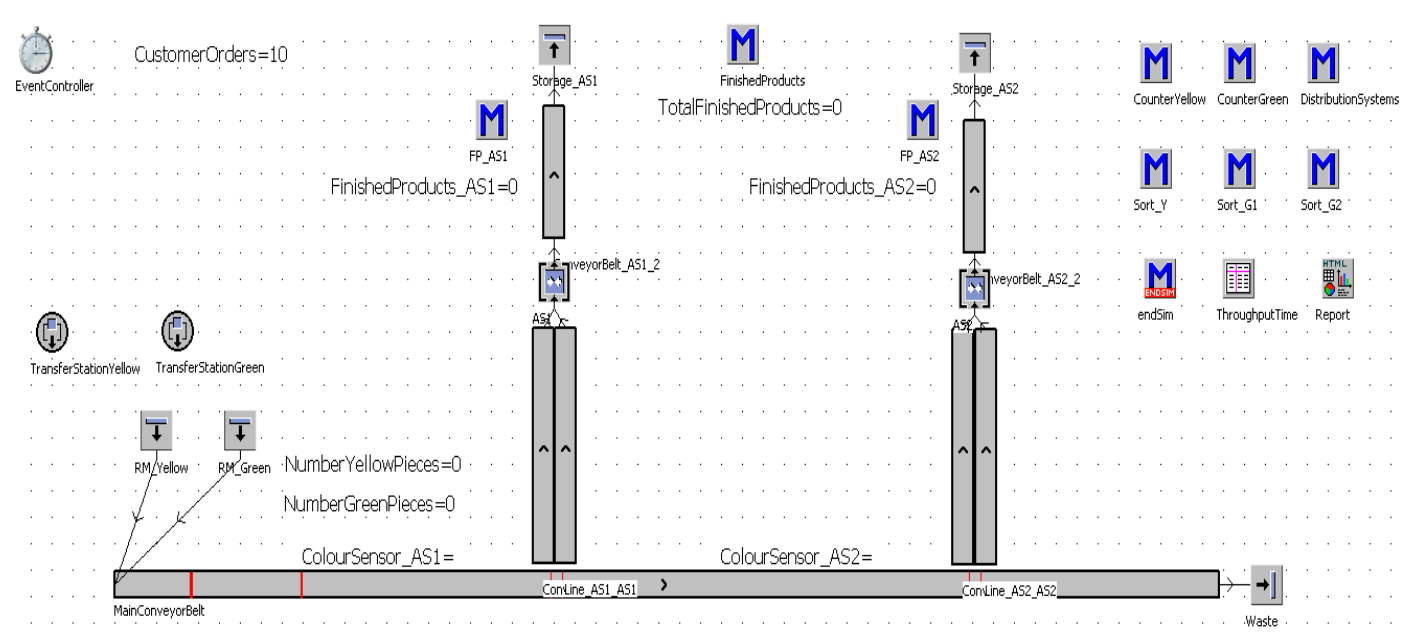

Figure 5. Lego ${ }^{\circledR}$ Model using Tecnomatix Plant Simulation 11.0.

The following data were collected from the physical model to be set in the simulation model:

- $\quad$ Lego ${ }^{\circledR}$ pieces inter-arrival rate;

- Conveyor belt speed;

- Processing time of the Assembly Station 1;

- $\quad$ Processing time of Assembly Station 2.

The normal probability distribution of the processing time of the assembly stations was verified using the probability plot method.

The Lego ${ }^{\circledR}$ simulation model was validated measuring the throughput time for both the simulation model and the physical system. Since the variables to be compared were mean values and the variances were unknown, the Student's $t$-test was chosen to test the null hypothesis $\mathrm{H}_{0}$ (i.e., the average throughput time of the simulation model is equal to the average throughput time of the physical system) and the alternative hypothesis $\mathrm{H}_{1}$ (i.e., the average throughput time of the simulation model is different from the average throughput time of the physical system).

To apply the Student's $t$-test, it was necessary to verify the normal distribution of throughput time data of both the simulation model and the physical system, and this was done using the probability plot method.

The results of the test are shown in Table 1. 
Table 1. Student's $t$-test results to validate the Lego ${ }^{\circledR}$ simulation model.

\begin{tabular}{ccc}
\hline & $t$-Test: Two-Sample Assuming Unequal Variances \\
\hline & Physical System & Simulation Model \\
\hline Mean & 0.004139468 & 0.00413566 \\
\hline Variance & $4.74067 \times 10^{-11}$ & $6.4552 \times 10^{-12}$ \\
\hline Observations $(\mathrm{n})$ & 10 & 10 \\
\hline Pooled Variance & 0 \\
\hline$\alpha$ & 0.05 \\
\hline Degrees of freedom $(\mathrm{n}-1)$ & 9 \\
\hline$t$ Stat & 1.640746409 \\
\hline $\mathrm{P}(\mathrm{T} \leq \mathrm{t})$ one-tail & 0.06455225 \\
\hline$t$ Critical one-tail & $1.795884814-1.833$ \\
\hline $\mathrm{P}(\mathrm{T} \leq \mathrm{t})$ two-tail & 0.129104501 \\
\hline$t$ Critical two-tail & 2.200985159 \\
\hline
\end{tabular}

Results show that with a significance level of $95 \%$, it was possible to state that the Lego ${ }^{\circledR}$ Simulation Model was valid.

Consequently, the simulation model was implemented in order to complete the research study.

The key parameter used to compare centralized and heterarchical control is the mean value of throughput time. The lowest throughput time identify the best control architecture.

The parameters modified during the experiments are:

- Number of customer orders;

- $\quad$ Positioning of the applied control;

- $\quad$ Lego ${ }^{\circledR}$ pieces interarrival rate;

- Failures in the Assembly Station 1.

It is worth underlining that the application of heterarchical control was valid because the processing time in Assembly Station 1 was higher than the time between the arrival of the Lego ${ }^{\circledR}$ green piece between the black wheels and the release of the following Lego ${ }^{\circledR}$ yellow piece. Otherwise, all the products would have been processed in the first assembly station and the application of heterarchical control on the production system would have not made any sense.

For the first scenario, six experimental cases were considered for both centralized and heterarchical control modifying the control variables for a total of 12 simulation scenarios (Table 2).

Table 2. Lego ${ }^{\circledR}$ simulation model parameters.

\begin{tabular}{|c|c|c|c|c|c|c|c|}
\hline \multicolumn{2}{|r|}{ Variables } & \multicolumn{6}{|c|}{$\begin{array}{c}\text { Centralized and Heterarchical Control } \\
\text { Architecture }\end{array}$} \\
\hline & & 1 & 2 & 3 & 4 & 5 & 6 \\
\hline Customer orders & $\begin{array}{c}10 \\
150\end{array}$ & $\bullet$ & $\bullet$ & $\bullet$ & $\bullet$ & $\bullet$ & $\bullet$ \\
\hline Control positioning & $\begin{array}{c}\text { Storage yellow Lego }{ }^{\circledR} \text { brick } \\
\text { assembly stations }\end{array}$ & $\bullet$ & $\bullet$ & $\bullet$ & $\bullet$ & $\bullet$ & $\bullet$ \\
\hline Lego ${ }^{\circledR}$ pieces interarrival rate & $\begin{array}{c}25.8 \mathrm{~s} \\
10 \mathrm{~s}\end{array}$ & $\bullet$ & $\bullet$ & $\bullet$ & $\bullet$ & $\bullet$ & $\bullet$ \\
\hline Random failures in AS1 & $\begin{array}{l}\text { Absent } \\
\mathrm{MTBF}=20 \mathrm{~min} \text { and } \mathrm{MTTR}=60 \mathrm{~min} \\
\mathrm{MTBF}=10 \mathrm{~min} \text { and } \mathrm{MTTR}=10 \mathrm{~min}\end{array}$ & $\bullet$ & $\bullet$ & $\bullet$ & $\bullet$ & $\bullet$ & $\bullet$ \\
\hline
\end{tabular}

NOTE: MTBF is the mean time between failures and MTTR is the mean time to repair.

\subsection{Scenario 2}

The simulation model built to reproduce the assembly process carried out in the EDF is reported in Figure 6. 


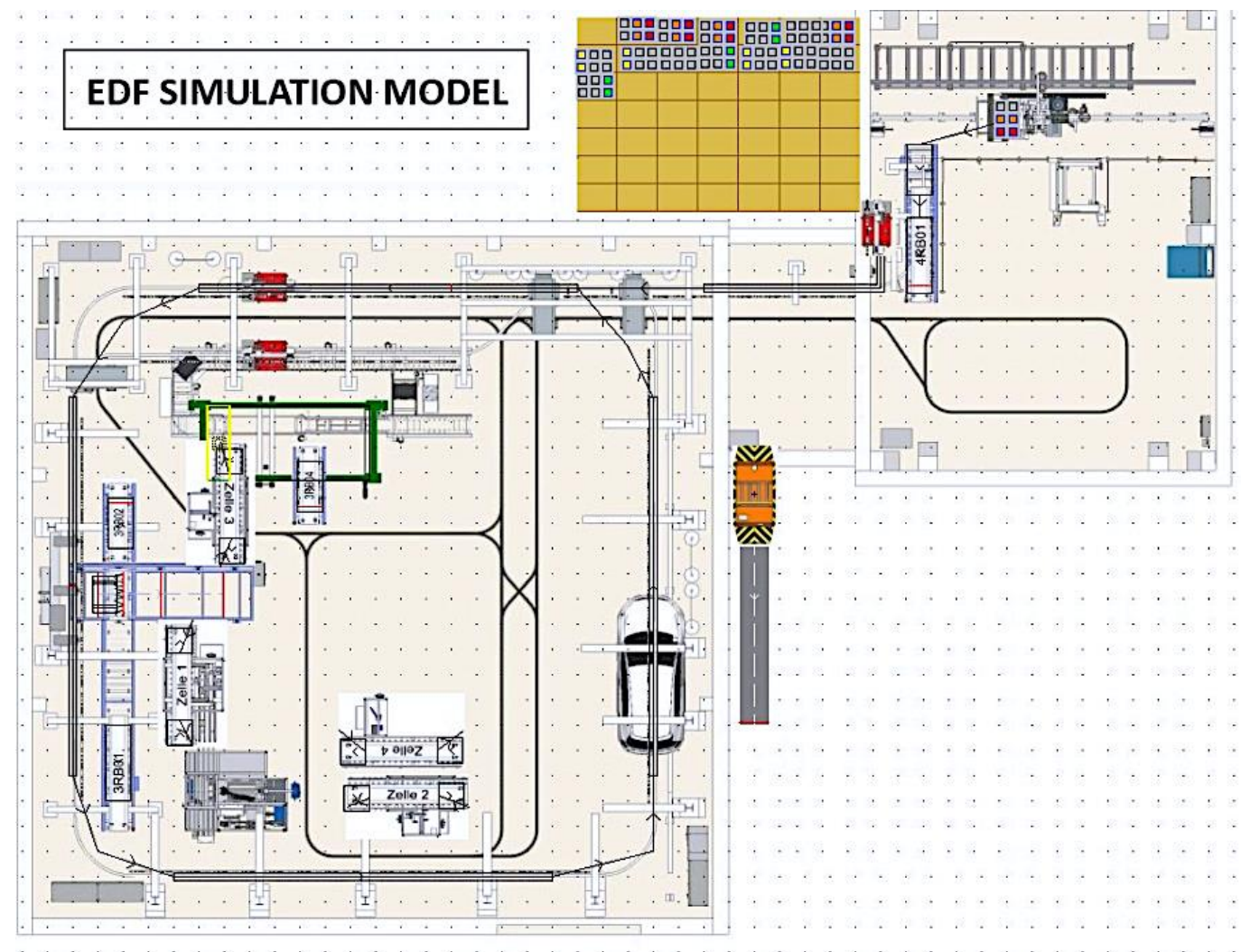

Figure 6. EDF simulation model.

It includes all the elements physically available in the factory: assembly cell, testing cell, production cell, disassembly cell, vertical warehouse, storage and repair system, AGV, EHB, portal, transfer carriage (3VW03), four roller conveyors. The following table (Table 3) reports the technical data of the simulation model components.

Table 3. Technical data of EDF simulation model $[43,45]$.

\begin{tabular}{|c|c|c|c|}
\hline Component & Description & Parameter & Value \\
\hline Manufacturing Cells & $\begin{array}{c}\text { Station with roller } \\
\text { conveyors }\end{array}$ & $\begin{array}{l}\text { Processing time } \\
\text { Length of conveyors } \\
\text { Capacity of cell }\end{array}$ & $\begin{array}{c}20 \mathrm{~s} \\
1 \mathrm{mt} \\
1\end{array}$ \\
\hline Transfer systems & $\begin{array}{c}\text { Transfer carriage } \\
\text { (3VW03) }\end{array}$ & $\begin{array}{c}\text { Length of the rail } \\
\text { Speed of the transfer system (3VW03) } \\
\text { Position of the transfer system of the EHB } \\
\text { Position of the roller conveyor of 3RB01/3RB02 } \\
\text { Position of the Cell 1 } \\
\text { Position of the Cell } 3\end{array}$ & $\begin{array}{l}5 \mathrm{mt} \\
0.4 \mathrm{~m} / \mathrm{s} \\
\text { at } 0 \mathrm{mt} \\
\text { at } 1 \mathrm{mt} \\
\text { at } 2.5 \mathrm{mt} \\
\text { at } 5 \mathrm{mt}\end{array}$ \\
\hline $\begin{array}{l}\text { Storage and } \\
\text { repair system }\end{array}$ & $\begin{array}{l}\text { Dedicated repair } \\
\text { operations }\end{array}$ & Average duration of bearing operations & $20 \mathrm{~s}$ \\
\hline $\begin{array}{l}\text { Roller conveyors } \\
\text { 3RB02/3RB04 }\end{array}$ & Conveyor & $\begin{array}{l}\text { Length } \\
\text { Speed } \\
\text { Capacity }\end{array}$ & $\begin{array}{c}2 \mathrm{mt} \\
0.4 \mathrm{~m} / \mathrm{s} \\
1 \text { pallet }\end{array}$ \\
\hline Portal & Portal crane & $\begin{array}{c}\text { Length } \\
\text { Width } \\
\text { Conveyor speed } \\
\text { Position of the supplier parts } \\
\text { Position of the removal parts } \\
\text { Admitted entities }\end{array}$ & $\begin{array}{l}5 \mathrm{mt} \\
2 \mathrm{mt} \\
0.4 \mathrm{~m} / \mathrm{s} \\
\text { at } 4 \mathrm{mt} \text { length and } 2 \mathrm{mt} \text { width } \\
\text { at } 1 \mathrm{mt} \text { length and } 2 \mathrm{mt} \text { width } \\
\text { Pallet and load carriages }\end{array}$ \\
\hline
\end{tabular}


Table 3. Cont.

\begin{tabular}{cccc}
\hline Component & Description & Parameter & Value \\
\hline & & Conveyor speed & $0.4 \mathrm{~m} / \mathrm{s}$ \\
Electric monorail & Transporter & Total length of route & Approx. $70 \mathrm{mt}$ \\
system (EHB) & & Position of the vertical storage & At 0 mt \\
& & At 32 mt & 2 \\
& & Number of vehicles & 49 pallets \\
Vertical warehouse & Space for pallets storage & Storage capacity & $7 \times 7$ storing positions \\
& & Storage dimension & Chaotic \\
\hline
\end{tabular}

Also, in this case, after the verification and validation of the model, the parameter chosen to test the system performance was the mean value of throughput time, while the parameters modified during the experiments were:

- Percentage of non-compliant products;

- AGV failures.

Product non-compliance probabilities were set to:

- $\quad 0 \%$, which means four products without failures;

- $25 \%$ which means one product with failures and three products without failures;

- $50 \%$ which means two products with failures and two products without failures;

- $75 \%$ which means three products with failures and one product without failures;

- $100 \%$ which means four products with failures.

Only the number of non-compliant products was fixed but not the order.

For this scenario, three experimental cases were considered and ten runs were launched for each experimental case for both centralized and heterarchical control. The following table summarizes the parameters assumed in the three experimental cases (Table 4).

Table 4. EDF simulation model parameters.

\begin{tabular}{|c|c|c|c|c|}
\hline \multicolumn{2}{|r|}{ Variables } & \multicolumn{3}{|c|}{$\begin{array}{l}\text { Centralized and Heterarchical } \\
\text { Control Architecture }\end{array}$} \\
\hline & & 1 & 2 & 3 \\
\hline$\%$ non-compliant products & $\begin{array}{c}0 \\
25 \\
50 \\
75 \\
100\end{array}$ & $\begin{array}{l}\bullet \\
\bullet \\
\bullet \\
\bullet \\
\bullet \\
\bullet\end{array}$ & $\begin{array}{l}0 \\
0 \\
0 \\
0 \\
0\end{array}$ & $\begin{array}{l}0 \\
0 \\
0 \\
0 \\
0 \\
0\end{array}$ \\
\hline Random AGV failures & $\begin{array}{l}\text { Absent } \\
\mathrm{MTBF}=3 \mathrm{~min} \text { and } \mathrm{MTTR}=1 \mathrm{~min} \\
\mathrm{MTBF}=9 \mathrm{~min} \text { and } \mathrm{MTTR}=1 \mathrm{~min}\end{array}$ & $\bullet$ & $\bullet$ & $\bullet$ \\
\hline
\end{tabular}

MTBF (Mean Time Between Failures); MTTR (Mean Time To Repair).

\section{Results and Discussion}

The simulations were run 20 times for each experimental condition in each scenario. The results obtained are detailed in the following subsections.

\subsection{Assembly Stations}

The simulation results obtained in the first experimental environment show that it is not possible to identify the best control architecture (Table 5). 
Table 5. Simulation results for the assembly station control. Throughput time expressed in minutes.

\begin{tabular}{cccccccc}
\hline & & \multicolumn{7}{c}{ Experimental Case Number and Throughput } \\
& & \multicolumn{5}{c}{ Time Results } \\
\cline { 3 - 8 } & & $\mathbf{1}$ & $\mathbf{2}$ & $\mathbf{3}$ & $\mathbf{4}$ & $\mathbf{5}$ & $\mathbf{6}$ \\
\hline \multirow{2}{*}{ Mean throughput time } & Centralized control & 4.937 & 4.932 & 25.504 & 25.578 & 83.882 & 33.502 \\
& Heterarchical control & 5.957 & 4.931 & 25.409 & 25.335 & 85.932 & 37.333 \\
\hline \multirow{2}{*}{$\begin{array}{c}\text { Non-manufactured finished } \\
\text { products number }\end{array}$} & Centralized control & 0 & 0 & 0 & 0 & 82 & 80 \\
& Heterarchical control & 0 & 0 & 0 & 0 & 0 & 0 \\
\hline
\end{tabular}

The results of the first experimental case show that the best result was obtained by applying centralized control, where the mean throughput time with centralized control was lower than the mean throughput time with heterarchical control.

For the second experimental case, the mean throughput time was almost the same for both control architectures, therefore centralized and heterarchical controls were comparable.

In the third experimental condition, the heterarchical control results were slightly better as compared to centralized control throughput time.

The fourth experimental case was different from the third one for the position where control was applied near the assembly stations. Also, in this case, the mean throughput time resulting from heterarchical control was lower than the mean throughput time resulting from centralized control. This means that the position where control was applied did not influence the results.

As for the last two experimental conditions, even if the throughput time resulting from centralized control was lower than that of heterarchical control, the time saved was not enough to compensate for the loss coming from the non-manufactured units. Indeed, under centralized control, in case of failure the production system was blocked and there were almost 80 units that could not be manufactured. Instead, under heterarchical control, it was possible to switch assembly stations in real time and process the materials without stopping the production process.

The results obtained from the six experimental cases demonstrate that for deterministic and predictable systems, centralized control is the best solution. However, this is an ideal condition, very far from the manufacturing reality. As soon as a failure occurs, a more flexible control is preferred because the time saved is not enough to cover the cost of non-manufactured units.

\subsection{Material Handling System Control}

The results obtained in the second experimental environment show that it is not possible to identify the best control architecture in absolute terms. Specifically, as expected, the results obtained in the first experimental case (Figure 7a) show that the centralized control is, for almost all the non-compliant product percentages, better than the heterarchical control. Except for the $50 \%$ of non-compliant products, the throughput time resulting from centralized control was always lower than the throughput time resulting from heterarchical control (Figure 7a). When AGV failures occur (second and third experimental case), the results of the runs do not show a homogeneous behavior (Figure $7 \mathrm{~b}, \mathrm{c}$ ). Sometimes centralized control is better than heterarchical controls and vice versa. However, the throughput time results of the runs obtained under heterarchical control present a standard deviation lower than centralized control architectures. This means that this configuration is able to manage more efficiently uncertainties and to operate the system more steadily in not predictable scenarios. Especially in vague situations, it can be beneficial to make the behavior respectively the outcome of a system more predictable because promises towards customers would be more reliable, subsequent processes could be aligned more easily, and less effort would be needed for adjustments to keep the system stability. 

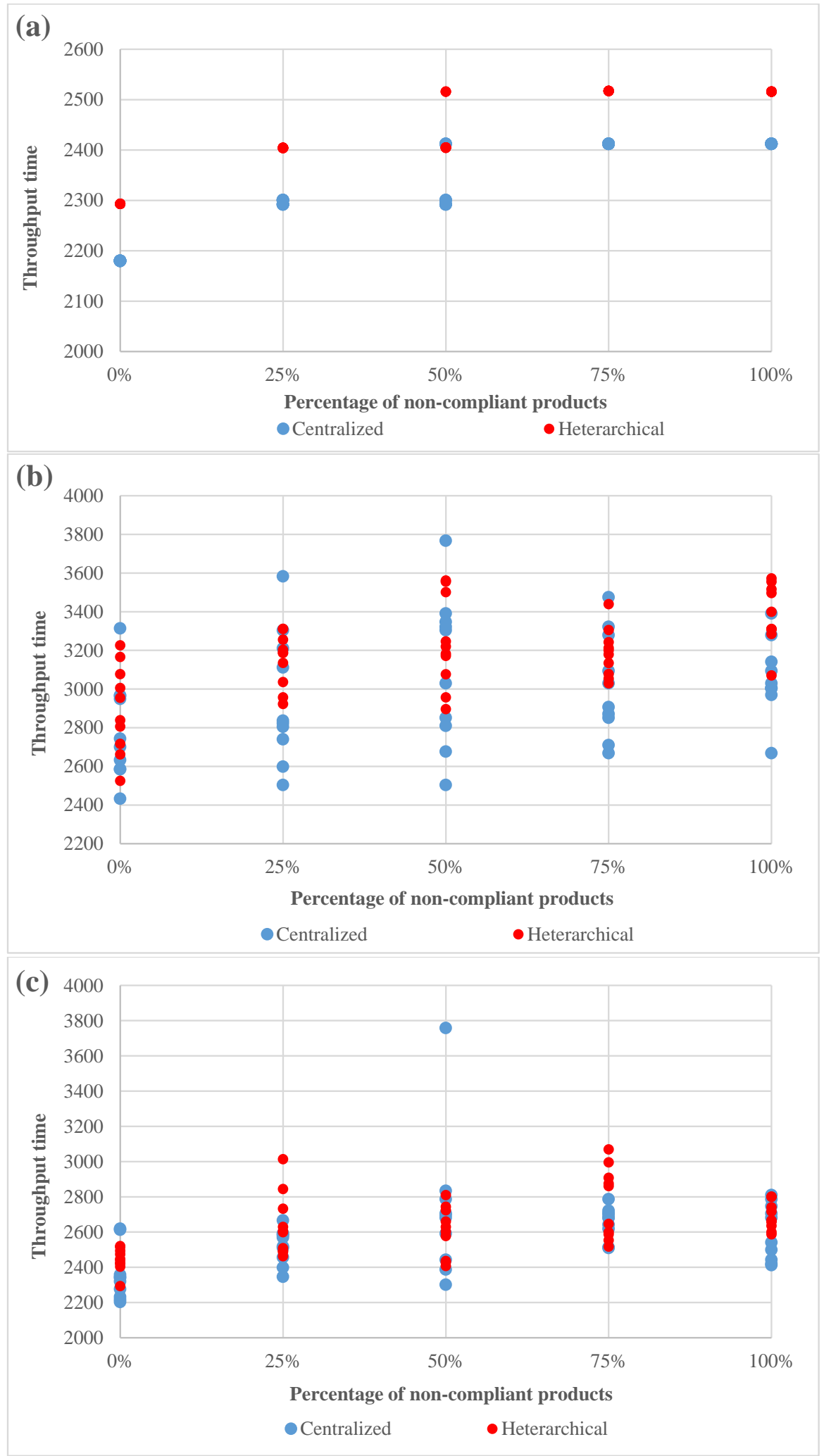

Figure 7. Simulation results for the material handling system control; (a) No AGV failures; (b) AGV failures: $\mathrm{MTBF}=3 \mathrm{~min}$ and $\mathrm{MTTR}=1 \mathrm{~min}$; (c) AGV failures: $\mathrm{MTBF}=9 \mathrm{~min}-\mathrm{MTTR}=1 \mathrm{~min}$. 


\section{Conclusions and Future Developments}

This paper deals with several features of modern manufacturing systems, from the concepts of flexibility and re-configurability to the evolution of their control architectures. An in-depth analysis of control architecture typologies was discussed, focusing on the comparison between centralized and heterarchical control architectures of assembly systems and material handling systems.

In the first scenario, the results confirm that, in case of failures, heterarchical control makes the production system more reliable. In the second scenario, the results of experiments show the advantage of heterarchical control in case of disruptions. In both scenarios, the advantages and disadvantages of centralized and heterarchical control implementation depend on the system conditions. More in detail, in a deterministic scenario, centralized control is clearly preferable, but in case of internal disruptions (e.g., machine failures), which are frequent in real situations, heterarchical control might be better. As a consequence of the characteristics of modern manufacturing systems, internal and external disruptions are numerous and frequent. Therefore, choosing a more flexible control system, better results might be obtained under the right conditions in terms of demand fulfilment, customers satisfaction, waste reduction, and cost decrease.

In terms of implications for practice, this study provides an implementation of centralized and heterarchical control systems using simulation that is applicable also in real-world scenarios. In this stage, combining physical models and simulation allows testing configurations that would be too complex and risky to be tested in real scenarios. On the contrary, physical prototypes are a useful tool for creating sensitivity, mutual understanding, for knowledge transfer, for showing but also restricting complexity, for making use of 'natural' deviations and also to lower the bar for later implementation in the real world. Similarly, digital models make it easy to investigate a wide range of scenarios by systematic parameter variations. Therefore, the combination of physical and digital models is required as a first steps towards creating CPS, which will be a (if not the) decisive element (or enabler) for decentralized control.

The applicability of the findings of this study to real scenarios will be quite relevant because the approach is very broad. The strategies investigated can be transferred to different production scenarios. However, the level or scope of transferability is dependent on the number of products/variants, the differences between them, the different features of the manufacturing processes simulated, and the stability of the manufacturing processes. The superiority of decentralized over centralized control is dependent on several factors which need to be investigated further and which are different for every single use case in a real factory. It is recommendable to implement decentralized control in a real scenario gradually, starting with single cells/workstations, up to lines, and the whole factory at the end.

Further research should focus on linking physical with digital models (preferably in real time) with special attention to control parameters, developing standardized simulation models for different control scenarios, developing general guidelines for the design of control structures and the implementation of CPS for decentralized control (e.g., infrastructure, necessary capabilities of the digital model, general data model, requirements on data quality, granularity, actuality).

Further studies are also required on the comparison between centralized and heterarchical control in more complex production systems, with more assembly stations, higher finished products diversification, diverse handling system typologies, as well as, applied control systems in order to demonstrate the potential advantages of autonomous control systems.

Secondly, the software tool adopted in this study captures operational performance metrics, but does not include environmental, economic, and social considerations. Future research involving programming-based studies should aim to extend the tool capabilities and provide greater flexibility and customizability.

Also, a detailed feasibility study including cost/complexity analysis should be performed before implementing a control system in real scenarios. Specifically, heterarchical control systems require significant investments in technologies (e.g., CPS and MAS) as well as costs related to the required technology competence of employees and top management. Despite this increasing complexity, 
the literature has shown the huge potential of the smart manufacturing systems in terms of flexibility and improved performance. These systems bring the capability to assist in managing system uncertainties and complexities through simulation scenarios providing valuable managerial insights prior to the deployment of smart manufacturing systems.

In conducting this study, some limitations are evident which, however, provide stimulating insights for expanding our research stream. Firstly, this paper is based on different scenarios in controlled experiments in a laboratory environment. In this sense, input from non-academic experts or practitioners may provide greater insights and would further facilitate generalizability of the provided findings.

Author Contributions: Conceptualization, R.R. and P.C.; methodology, T.M.; software, A.R.B. and R.R.; validation, T.M. and R.R.; formal analysis, A.R.B.; investigation, A.R.B. and R.R.; resources, T.M. and R.R.; writing-original draft preparation, P.C.; writing-review and editing, P.C. and R.C.; visualization, P.C.; supervision, R.C. and R.R.; project administration, R.R. All authors have read and agreed to the published version of the manuscript.

Funding: This research received no external funding.

Acknowledgments: The authors would like to express their gratitude to the institutions that have supported this work providing the necessary equipment, software as well as scientific advice, namely the Department of Chemical, Materials and Industrial Production Engineering and the Department of Industrial Engineering of the University of Naples Federico II (Italy) and the Department of Factory Planning and Factory Management of the Technische Universität Chemnitz (Germany).

Conflicts of Interest: The authors declare no conflict of interest.

\section{References}

1. Moghaddam, M.; Cadavid, M.N.; Kenley, C.R.; Deshmukh, A.V. Reference architectures for smart manufacturing: A critical review. J. Manuf. Syst. 2018, 49, 215-225. [CrossRef]

2. Axelsson, J.; Fröberg, J.; Eriksson, P. Architecting systems-of-systems and their constituents: A case study applying Industry 4.0 in the construction domain. Syst. Eng. 2019, 22, 455-470. [CrossRef]

3. Chryssolouris, G.; Mavrikios, D.; Papakostas, N.; Mourtzis, D.; Michalos, G.; Georgoulias, E.K. Digital manufacturing: History, perspectives, and outlook. J. Eng. Manuf. 2009, 223, 451-462. [CrossRef]

4. Mehrpouya, M.; Dehghanghadikolaei, A.; Fotovvati, B.; Vosooghnia, A.; Emamian, S.S.; Gisario, A. The potential of additive Manufacturing in the smart factory industrial 4.0. Appl. Sci. 2019, 9, 38-65. [CrossRef]

5. Lu, Y.; Morris, K.; Frechette, S. Current Standards Landscape for Smart Manufacturing Systems; National Institute of Standards and Technology: Gaithersburg, MD, USA, 2016.

6. Moghaddam, M.; Nof, S. Collaborative service-component integration in cloud manufacturing. Int. J. Prod. Res. 2018, 56, 677-691. [CrossRef]

7. Telgen, D.; van Moergestel, L.; Puik, E.; Streng, A.; Scheefhals, R.; Bakker, T.; Hustinx, A.; van den Brink, L.; Meyer, J.J. Hierarchical Management of a Heterarchical Manufacturing Grid. In Proceedings of the 24th International Conference on Flexible Automation \& Intelligent Manufacturing FAIM 2014, San Antonio, TX, USA, 20-23 May 2014.

8. Dilts, D.M.; Boyd, N.P.; Whorms, H.H. The evolution of control architectures for automated manufacturing systems. J. Manuf. Syst. 1991, 10, 79-93. [CrossRef]

9. Radziwon, A.; Bilberg, A.; Bogers, M.; Madsen, E. The smart factory: Exploring adaptive and flexible manufacturing solutions. Procedia. Eng. 2014, 69, 1184-1190. [CrossRef]

10. Caridi, M.; Cavalieri, S. Multi-agent systems in production planning and control: An overview, Production Planning \& Control. Manag. Oper. 2004, 15, 106-118.

11. Koren, Y.; Shpitalni, M. Design of reconfigurable manufacturing systems. J. Manuf. Syst. 2010, $29,130-141$. [CrossRef]

12. Browne, J.; Dubois, D.; Rathmill, K.; Sethi, S.; Stecke, K.E. Classification of flexible manufacturing systems. FMS Mag. 1984, 2, 114-117.

13. Răileanu, S. Production scheduling in a holonic manufacturing system using the open-control concept. UPB Sci. Bull. Ser. C Electr. Eng. 2010, 72, 39-52.

14. Angelva, J.; Piltonen, P. Real-time data management in a flexible manufacturing system (FMS). J. Mater. Process. Technol. 1995, 52, 76-82. [CrossRef] 
15. ElMaraghy, H.A. Flexible and reconfigurable manufacturing systems paradigms. Int. J. Flex. Manuf. Syst. 2005, 17, 261-276. [CrossRef]

16. Da Silveira, M.R.; Combacau, M. Supervision and control of heterarchical discrete event system. Controle Autom. 2006, 17, 1-9. [CrossRef]

17. Saharidis, G.K. Supply Chain Optimization: Centralized vs Decentralized Planning and Scheduling. In Supply Chain Management; IntechOpen: London, UK, 2011.

18. Rana, S.P.; Taneja, S.K. A distributed architecture for automated manufacturing systems. Int. J. Adv. Manuf. Technol. 1988, 3, 81-98. [CrossRef]

19. Duffie, N.; Chitturi, R.; Mou, J. Fault-tolerant heterarchical control of heterogeneous manufacturing system entities. J. Manuf. Syst. 1988, 7, 315-328. [CrossRef]

20. Hatvany, J. Intelligence and Cooperation in Heterarchic Manufacturing Systems. Robot. Comput. Integr. Manuf. 1985, 2, 101-104. [CrossRef]

21. Shaw, M.J. Dynamic Scheduling in Cellular Manufacturing Systems: A Framework for Networked Decision Making. J. Manuf. Syst. 1988, 7, 83-94. [CrossRef]

22. NDuffie, A.; Piper, R.S. Non-Hierarchical Control of a Flexible Manufacturing Cell. Robot. Comput. Integr. Manuf. 1987, 3, 175-179.

23. Duffie, N. An Approach to the Design of Distributed Machinery Control Systems. IEEE Trans. Ind. Appl. 1982, IA-18, 435-442. [CrossRef]

24. Zou, X.; Pokharel, S.; Piplani, R. A two-period supply contract model for a decentralized assembly system. Eur. J. Oper. Res. 2008, 187, 257-274. [CrossRef]

25. Brennan, R.W.; Douglas, H.N. Evaluating the performance of reactive control architectures for manufacturing production control. Comput. Ind. 2001, 46, 235-245. [CrossRef]

26. Adam, E.; Berger, T.; Sallez, Y.; Trentesaux, D. An Open-Control Concept for a Holonic Multiagent System. In Holonic and Multi-Agent Systems for Manufacturing. HoloMAS 2009; Lecture Notes in Computer Science; Mařík, V., Strasser, T., Zoitl, A., Eds.; Springer: Berlin/Heidelberg, Germany; Volume 5696.

27. Raileanu, S.; Berger, T.; Sallez, Y.; Borangiu, T.; Trentesaux, D. The open-control concept for holonic manufacturing. Int. J. Mech. Control 2010, 11, 13-20.

28. Hongler, M.O.; Gallay, O.; Hülsmann, M.; Cordes, P.; Colmorn, R. Centralized versus decentralized control—A solvable stylized model in transportation. Phys. A Stat. Mech. Its Appl. 2010, 389, 4162-4171. [CrossRef]

29. Telgen, D.; Puik, E.; van Moergestel, L.; Meyer, J.J. Distributed and Heterarchical Control for Grid Manufacturing. In Proceedings of the SICE Annual Conference (SICE), Nagoya, Japan, 14-17 September 2013.

30. Van Moergestel, L.; Puik, E.; Telgen, D.; Meyer, J.J. Implementing Manufacturing as a Service:A Pull-Driven Agent-Based Manufacturing Grid. In Proceedings of the 11th International Conference on ICT in Education, Research and Industrial Applications: Integration, Harmonization and Knowledge Transfer, Lviv, Ukraine, 14-16 May 2015.

31. Monostori, L.; Váncza, J.; Kumara, S.R. Agent-based systems for manufacturing. CIRP Ann. Manuf. Technol. 2006, 55, 697-720. [CrossRef]

32. Rodrigues, N.; Oliveira, E.; Leitao, P. Decentralized and on-the-fly agent-based service reconfiguration in manufacturing systems. Comput. Ind. 2018, 101, 81-90. [CrossRef]

33. Bochmann, L.; Gehrke, L.; Bockenkamp, A.; Weichert, F.; Albersmann, R.; Prasse, C.; Mertens, C.; Motta, M.; Wegener, K. Towards Decentralized Production:A Novel Method to Identify Flexibility Potentials in Production Sequences Based on Flexibility Graphs. Int. J. Autom. Technol. 2015, 9, 270-282. [CrossRef]

34. Quintanilla, F.G.; Cardin, O.; Castagna, P. Evolution of a flexible manufacturing system: From communicating to autonomous product. In Service Orientation in Holonic and Multi Agent Manufacturing and Robotics; Springer: Berlin, Germany, 2015; Volume 472, pp. 167-180.

35. Ramli, R.; Yamamoto, H.; Sulong, A.B.; Wahab, D.A.; Qudeiri, J.A. Real-time AGV action decision in AD-FMS by hypothetical reasoning. Eur. J. Sci. Res. 2009, 25, 310-324.

36. Hussnain, A.; Ferrer, B.R.; Martinez Lastra, J.L. An application of cloud robotics for enhancing the flexibility of robotic cells at factory shop floors. In Proceedings of the 44th Annual Conference of the IEEE Industrial Electronics Society, Washington, DC, USA, 21-23 October 2018; pp. 2963-2970.

37. Brennan, R.W.; Douglas, H.N. Metrics for evaluating distributed manufacturing control systems. Comput. Ind. 2003, 51, 225-235. [CrossRef] 
38. Moyaux, T.; McBurney, P. Centralized vs. market-based and decentralized decision making: A review. Cybern. Syst. 2012, 43, 567-622. [CrossRef]

39. Sugi, M.; Nikaido, M.; Tamura, Y.; Ota, J.; Arai, T.; Kotani, K.; Takamasu, K.; Shin, S.; Suzuki, H.; Sato, Y. Motion control of self-moving trays for human supporting production cell "attentive workbench". In Proceedings of the IEEE International Conference on Robotics and Automation, Barcelona, Spain, 18-22 April 2005.

40. Salcedo, C.A.G.; Hernandez, A.I.; Vilanova, R.; Cuartas, J.H. Inventory control of supply chains: Mitigating the bullwhip effect by centralized and decentralized Internal Model Control approaches. Eur. J. Oper. Res. 2013, 224, 262-272.

41. Ramli, R.; Yamamoto, H.; Qudeiri, J.A. Hypothetical reasoning approach for Automated Guided Vehicle action decision in Autonomous Decentralised Flexible Manufacturing Systems. Int. J. Intell. Syst. Technol. Appl. 2009, 7, 171-187. [CrossRef]

42. Kuehn, W. Digital Factory-Integration of Simulation Enhancing the Product and Production Processes Towards Operative Control and Optimisation. Int. J. Simul. Syst. Sci. Technol. 2006, 7, 27-39.

43. Güldenpfennig, E. Technische Projectarbeit: Entwicklung und Umsetzung eines Materialflusssimulationsmodells für die Experimentier und Digitalfabrik; des Bachelorsstudiengangs, Technische Universitat Chemnitz: Chemnitz, Germany, 2011.

44. Leduc, R.J.; Lawford, M.; Dai, P. Hierarchical interface-based supervisory control of a flexible manufacturing system. IEEE Trans. Control Syst. Technol. 2006, 14, 654-668. [CrossRef]

45. Ackermann, J. Layout der Experimentier-und Digitalfabrik; des Bachelorsstudiengangs, Technische Universitat Chemnitz: Chemnitz, Germany, 2011.

(C) 2020 by the authors. Licensee MDPI, Basel, Switzerland. This article is an open access article distributed under the terms and conditions of the Creative Commons Attribution (CC BY) license (http://creativecommons.org/licenses/by/4.0/). 